Diabetologia 10, $329-335$ (1974)

(C) by Springer-Verlag 1974

\title{
Metabolic and Hormonal Effects of Exercise in the Severely Streptozotocin-Diabetic Rat*
}

\author{
V.A. Koivisto, H.K. Åkerblom and M.K. Kiviluoto \\ The Children's Hospital, University of Helsinki, Helsinki, and the Department of Pediatrics, University of Oulu, \\ Oulu, Finland \\ Received: December 20, 1973, and in revised form: April 16, 1974
}

\begin{abstract}
Summary. Metabolic and hormonal changes during muscular exercise were studied in streptozotocin $(65$ $\mathrm{mg} / \mathrm{kg}$ ) - diabetic rats. The untreated, non-fasted animals ran in a rotating cage for $30 \mathrm{~min}$, and blood, liver and pancreatic specimens were taken before, immediately after and/or two hrs after exercise. The slight preexercise acidosis of the diabetic rats changed during exercise to a marked acidosis due to a rise in blood lactate. High blood glucose fell in 33 out of 54 animals, while hepatic glycogen was low and unchanged. A marked increase in circulating glycerol was found, whereas plasma free fatty acids (FFA) decreased and the fall of FWA was glucose "sparing". In animals, in which blood glucose
\end{abstract}

decreased, plasma immunoreactive insulin (IRI) rose significantly and the rise correlated with the fall in blood glucose and with the intensity of work. Exercise did not affect the low pancreatic content of IRI. The results add weight to the suggestion that in severe, acute diabetes muscular work can mobilize IRI, perhaps of extrapancreatic origin, which helps to explain the decrease in circulating glucose.

Key words: Acetone bodies, corticosterone, diabetes, exercise, FFA, glucose, glycerol, glycogen, insulin, lactate, rat, streptozotocin.
Reports published before the discovery of insulin demonstrated harmful metabolic effects of muscular work in severe diabetes mellitus due to further enhancement of ketoacidosis [1]. This occurs in the absence of insulin due to increased lipid mobilization during exercise $[2,3]$. The plasma level of free fatty acids (FFA) rises $[3,4]$ leading to overproduction of acetone bodies in the liver [5] and hyperketonemia ensues [6]. In experimental diabetes, during marked insulin deficiency, peripheral underutilization of circulating acetone bodies augments hyperketonemia $[6,7]$.

On the other hand, in the complete absence of insulin exercise increases the rate of oxidation of blood glucose in dogs [8]. This exercise-induced hypoglycemia has been explained by a humoral hypoglycemic factor, effective also in the diabetic organism [9]. However, Goldstein's theory [9] has met criticism [10] and the changes in blood glucose due to exercise have been contradictory in severely diabetic dogs [11].

The present study was performed in order to obtain more information about the interrelationship between carbohydrate and lipid metabolism and their hormonal regulation during and after exercise in severe diabetes.

\section{Material and Methods}

\section{Rats}

Male Sprague-Dawley rats, weighing from 300 to $350 \mathrm{~g}$ were used. They were untrained and fed a normal

* Parts of this study have been presented at the annual meetings of the Scandinavian Society for the Study of Diabetes in Stockholm March 1, 1972 and in Arhus May 26, 1973, and at the annual meeting of the European Society for Paediatric Endocrinology in Louvain September 10, 1972. commercial chow ${ }^{1}$ ad libitum until the beginning of the exercise experiment.

\section{The Induction of Diabetes}

Streptozotocin ${ }^{2}$ was prepared in 0.1 molar citrate buffer, pH 4.5. 1-2 min after dissolution the drug was injected in a dose of $65 \mathrm{mg} / \mathrm{kg}$ of body weight in a $3 \%$ solution intravenously. An equal volume of buffer was injected into control animals. The development of diabetes was followed by measuring the loss of weight and the consumption of water, and by estimating glucosuria by Clinitest ${ }^{\circledR 3}$ and ketonuria by Ketostix ${ }^{\circledR 3}$. The changes in blood glucose, acetone bodies and plasma immunoreactive insulin (IRI) were also measured in some of the animals $40 \mathrm{~min}$, and two, six, 24, 30 and $51 \mathrm{~h}$ after the injection of streptozotocin.

\section{The Experimental Procedure}

The diabetic rats were not treated with insulin. $42-48 \mathrm{~h}$ after the injection of streptozotocin the animals ran for $30 \mathrm{~min}$ in a cage which was rotated at a constant speed. Blood specimens were taken before exercise, immediately after and two hours after the end of running. The pancreas and the liver were removed either before exercise, immediately after or two hours after the exercise. While blood specimens were taken and the pancreas was removed the animal was lightly anaesthetized with ether. Some of the animals in each experiment were non-diabetic controls.

1 The chow contains by weight $49.6 \%$ carbohydrate, $22.3 \%$ protein, $5.7 \%$ fat, and usual vitamins and minerals.

2 Upjohn \& Co, lot 9164-VDV-59 U9889 and lot 9681-GGS-118FJ

3 Ames \& Co 


\section{Handling of Blood Specimens}

Blood was drawn from the retro-orbital venous plexus through a heparinized capillary tube and collected in ice-cold tubes. Capillary tubes for $\mathrm{pH}$ determination were filled immediately and kept at $+4^{\circ} \mathrm{C}$ until analysis, which took place within one hour. Specimens for the measurement of blood glucose, lactate and acetone bodies were taken. The tubes were spun and plasma removed for the determination of glycerol, FTA, IRI, and corticosterone. The heparinized blood (for the determination of acetone bodies) and the plasma specimens were kept at $-20^{\circ} \mathrm{C}$ until analysis.

\section{Chemical Methods}

a) Blood Parameters. 1. Blood glucose was measured by a glucose oxidase method [12].

2. Lactate was determined enzymatically with the Biochemica "Boehringer" (Mannheim, West Germany) test kit [13].

3. $\mathrm{pH}$ was analyzed by a capillary electrode [14].

4. Plasma glycerol was determined fluorimetrically according to the enzymatic micromethod of Laurell and Tibbling $[15]$.

5. Plasma FFA was measured according to Novak [16], using a plasma volume of $100 \mu l$.

6. Blood acetoacetate +acetone and $\beta$-hydroxybutyrate were analyzed by the microdistillation method of Ahola and Somersalo [17] using furfural as colour reagent.

7. Plasma insulin was assayed radioimmunologically by a modification of the method of Herbert et al. [18]: After $20 \mathrm{~h}$ preincubation ${ }^{125}$ I-insulin was added. The total incubation period was $48 \mathrm{~h}$ at $+4^{\circ} \mathrm{C}$, whereupon bound and free insulin were separated by activated charcoal. Dextran was not necessary in the separation. The standard preparation was Batch $\mathrm{R} 170$ of rat insulin. ${ }^{4}$ The sensitivity of the method was $0.1 \mathrm{ng} / \mathrm{ml} .{ }^{5}$

8. Plasma corticosterone was measured fluorimetrically according to the method of Spencer-Peet et $a l .[19]$, modified to a plasma volume of $100 \mu l$.

IRI was determined in quadruplicates, the other parameters in duplicates.

b) Liver Glycogen. The rat was killed by decapitation, the liver was quickly removed and frozen. Hepatic glycogen was split by acid hydrolysis according to Chernick et al. [20], whereafter glucose was determined [12a]. The results are expressed as $\mathrm{mg}$ of glycogen/g of liver. Standards of purified glyeogen from rabbit liver ${ }^{6}$ were referred to throughout the procedure.

c) Pancreatic IRI. After removal, the pancreas was frozen immediately for insulin extraction, using acid ethanol $[21,22]$. IRI was assayed from the diluted extract as reported for plasma IRI. The results are expressed as $\mu \mathrm{g}$ of IRI/mg of pancreas.

4 A gift of NOVO Research Institute, Copenhagen, Denmark.

$51 \mathrm{ng}$ of insulin $/ \mathrm{ml}=24.5 \mu \mathrm{U} / \mathrm{ml}$.

6 Sigma Ltd, type III lot $75 \mathrm{~B}-1820$
The statistical significance of differences between mean values was calculated using Student's $t$-test.

\section{Results}

$42-48 \mathrm{~h}$ after the injection of streptozotocin at $65 \mathrm{mg} / \mathrm{kg}$ of body weight all rats had become severely diabetic. The average water consumption increased from $30 \mathrm{ml}$ to $140 \mathrm{ml}$ (range $70-220 \mathrm{ml}$ ) during the final $24 \mathrm{~h}$, and the mean loss of weight after the injection was $11 \%(6-16 \%)$. The changes in blood glucose, acetone bodies and plasma IRI, and the glucosuria and ketonuria readings during the induction of diabetes are seen in Table 1.

\section{Blood Lactate and $p H$}

The intensity of muscular work was confirmed by the determination of blood lactate. The increase was highly significant in both groups: 2.6 -fold in controls (Table 2) and 4.2-fold in diabetic animals (Table 3). The increase in blood lactate correlated with the decrease in $\mathrm{pH}$, the correlation coefficient $(\mathrm{r})$ being 0.77 in the controls and 0.72 in the diabetic rats $(p<0.001$ in both groups).

\section{Blood Glucose}

The changes in blood glucose are seen in Fig. 1. In diabetic animals the mean decrease during exercise was highly significant, but the effect was of short duration. However, in 21 out of 54 animals the blood glucose actually increased. Table 4 shows the blood glucose values separately in those diabetic rats whose blood glucose decreased and in those which did not exhibit a decrease during exercise. The mean blood glucose values of the two subgroups were not significantly different before exercise. The decrease of circulating glucose in group 1 correlated with the rise in lactate $(\mathrm{r}=0.54, p<0.02)$. In group 1 the rise of blood lactate was higher than in group $2(p<0.02)$. At the end of exercise the circulating level of glucose correlated inversely with that of lactate in group $1(\mathrm{r}=$ $-0.55, p<0.001)$.

\section{Liver Glycogen}

In control animals the highly significant increase in blood glucose during exercise corresponded with a remarkable decrease in hepatic glycogen, which is shown in Fig. 2. In diabetic rats liver glycogen was $7.1 \%$ of that in controls before exercise, and no change was seen during or after exercise (Fig. 2). PAS-staining of liver glyeogen confirmed results obtained by the chemical method [23].

\section{Plasma IRI}

The fourfold rise in plasma IRI from a hypo- to normoinsulinemic level in severely diabetic rats during muscular work is seen in Fig. 3. The increase - minor or major - was found in 31 out of 47 rats. Table 4 shows separately the mean changes of plasma IRI in the two subgroups of the diabetic rats according to the 
Table 1. The induction of diabetes in the rat, as judged from the concentrations of blood glucose, acetone bodies and plasma $I R I$, and the glucosuria and ketonuria readings after the $I . V$. injection of streptozotocin at $65 \mathrm{mg} / \mathrm{kg}$. Mean $\pm S E M$ and the number of animals are given

\begin{tabular}{|c|c|c|c|c|c|c|c|}
\hline & $0 \mathrm{~min}$ & $40 \mathrm{~min}$ & $2 \mathrm{~h}$ & $6 \mathrm{~h}$ & $24 \mathrm{~h}$ & $30 \mathrm{~h}$ & $51 \mathrm{~h}$ \\
\hline \multicolumn{8}{|l|}{ Blood glucose, } \\
\hline $\mathrm{m}_{\mathrm{n}}^{\mathrm{mg} / 100 \mathrm{ml}}$ & $\begin{array}{l}100 \pm 4 \\
10\end{array}$ & $\begin{array}{c}126 \pm 5 \\
10\end{array}$ & $\begin{array}{l}283 \pm 11 \\
10\end{array}$ & $\frac{136 \pm 19}{7}$ & $\begin{array}{r}337 \\
10\end{array}$ & $\frac{325}{7} \pm 21$ & $\begin{array}{c}320 \pm 12 \\
10\end{array}$ \\
\hline$p<($ vs. $0 \mathrm{~min})$ & - & 0.001 & 0.001 & n.s. & 0.001 & 0.001 & 0.001 \\
\hline \multicolumn{8}{|l|}{ Blood total } \\
\hline $\mathrm{mmol} / \mathrm{l}$ & $0.23 \pm 0.02$ & $0.21 \pm 0.02$ & $0.90 \pm 0.13$ & $0.44 \pm 0.15$ & $1.08 \pm 0.10$ & $1.81 \pm 0.22$ & $5.88 \pm 0.83$ \\
\hline $\mathrm{n}$ & 10 & 10 & 10 & 7 & 10 & & \\
\hline$p<($ vs. $0 \min )$ & - & n.s. & 0.001 & n.s. & 0.001 & 0.001 & 0.001 \\
\hline $\begin{array}{l}\text { Plasma 1K1, } \\
\mathrm{ng} / \mathrm{ml}\end{array}$ & $3.5 \pm 0.8$ & $3.0 \pm 1.3$ & $0.73 \pm 0.15$ & $4.6+0.7$ & $1.2+0.8$ & $0.63 \pm 0.21$ & $0.80 \pm 0.4$ \\
\hline $\mathrm{n}$ & 10 & 10 & 10 & 7 & 10 & 7 & 10 \\
\hline$p<($ vs. $0 \mathrm{~min})$ & - & n.s. & 0.005 & n.s. & 0.05 & 0.005 & 0.01 \\
\hline Clinitest $\left({ }^{\circ}\right.$ & - & - & $5 \%$ & - & $5 \%$ & $5 \%$ & $5 \%$ \\
\hline Ketostix ${ }^{\circledR}$ & - & - & + & - & + & ++ & $+t+$ \\
\hline
\end{tabular}

Table 2.Blood lactate and $p H$ in control rats before and after 30 min exercise. Mean \pm $S E M$ and the number of animals are given

\begin{tabular}{llll}
\hline & $\begin{array}{l}\text { Before } \\
\text { exercise }\end{array}$ & $\begin{array}{l}\text { Immediately } \\
\text { after exercise }\end{array}$ & $\begin{array}{l}120 \text { min } \\
\text { after exercise }\end{array}$ \\
\hline Blood lactate, mmol $/ 1$ & $2.1 \pm 0.16^{\mathrm{a}, \mathrm{b}}$ & $5.5 \pm 0.52^{\mathrm{a}, \mathrm{c}}$ & $1.1 \pm 0.06^{\mathrm{b}, \mathrm{c}}$ \\
$\mathrm{n}$ & 21 & 27 & 9 \\
$\mathrm{pH}$ & $7.36 \pm 0.01^{\mathrm{a}}$ & $7.28 \pm 0.02^{\mathrm{a}}, \mathrm{b}$ & $7.36 \pm 0.01^{\mathrm{b}}$ \\
$\mathrm{n}$ & 38 & 36 & 26 \\
\hline
\end{tabular}

$$
\begin{aligned}
& \mathrm{a}=p<0.001 \\
& \mathrm{~b}=p<0.001 \\
& \mathrm{c}=p<0.001
\end{aligned}
$$

Table 3. Blood lactate and $p H$ in streptozotocin $(65 \mathrm{mg} / \mathrm{kg})$-diabetic rats before and after 30 min exercise. Mean $\pm S E M$ and the number of animals are given

\begin{tabular}{llll}
\hline & $\begin{array}{l}\text { Before } \\
\text { exercise }\end{array}$ & $\begin{array}{l}\text { Immediately } \\
\text { after exercise }\end{array}$ & $\begin{array}{l}120 \text { min } \\
\text { after exercise }\end{array}$ \\
\hline Blood lactate, $\mathrm{mmol} / \mathrm{l}$ & $\mathbf{1 . 7} \pm 0.12^{\mathrm{a}}$ & $7.1 \pm 0.40^{\mathrm{a}, \mathrm{b}}$ & $\mathbf{1 . 9} \pm 0.20^{\mathrm{b}}$ \\
n & $\mathbf{2 6}$ & $\mathbf{5 4}$ & $\mathbf{1 5}$ \\
pH & $\mathbf{7 . 2 5} \pm 0.02^{\mathrm{a}}$ & $7.11 \pm 0.02^{\mathrm{a}}, \mathrm{b}$ & $\mathbf{7 . 2 7} \pm 0.02^{\mathrm{b}}$ \\
$\mathrm{n}$ & $\mathbf{7 5}$ & 65 & $\mathbf{3 4}$ \\
\hline
\end{tabular}

$\mathrm{a}=p<0.001$

$\mathrm{b}=p<0.001$

Table 4. Blood glucose and plasma IRI (mean $\perp$ SEM) before and after exercise in streptozotocin $(65 \mathrm{mg} / \mathrm{kg})$-diabetic rats. Group $1 \equiv$ rats, whose blood glucose decreased, group $2=$ rats, whose blood glucose increased during exercise. Mean $\pm S E M$ and the number of animals are given

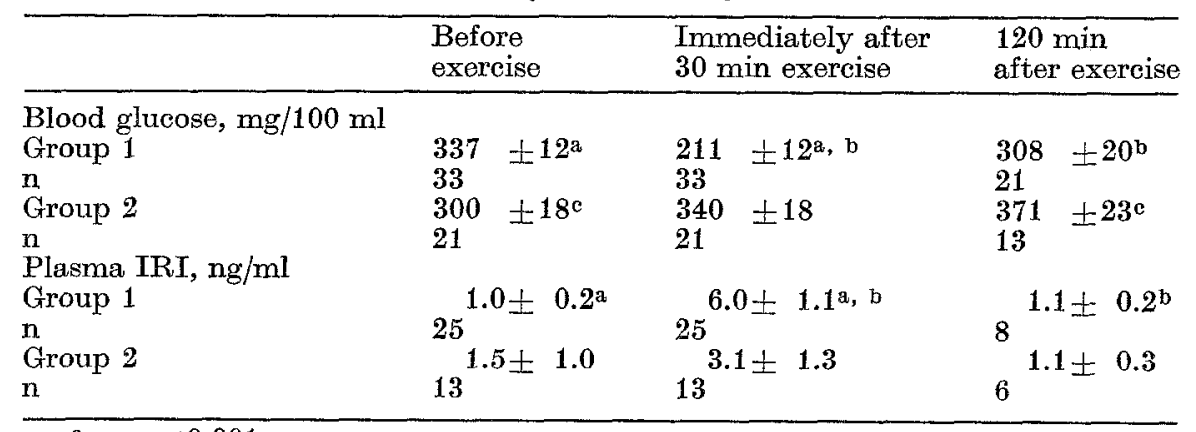

$$
\begin{aligned}
& \mathrm{a}=p<0.001 \\
& \mathrm{~b}=p<0.001 \\
& \mathrm{c}=p<0.025
\end{aligned}
$$


changes in blood glucose. In group 1 the rise in plasma IRI correlated with the decrease in blood glucose $(\mathrm{r}=$ $0.42, p<0.02)$ and with the increase in blood lactate $(\mathbf{r}=0.58, p<0.01)$.

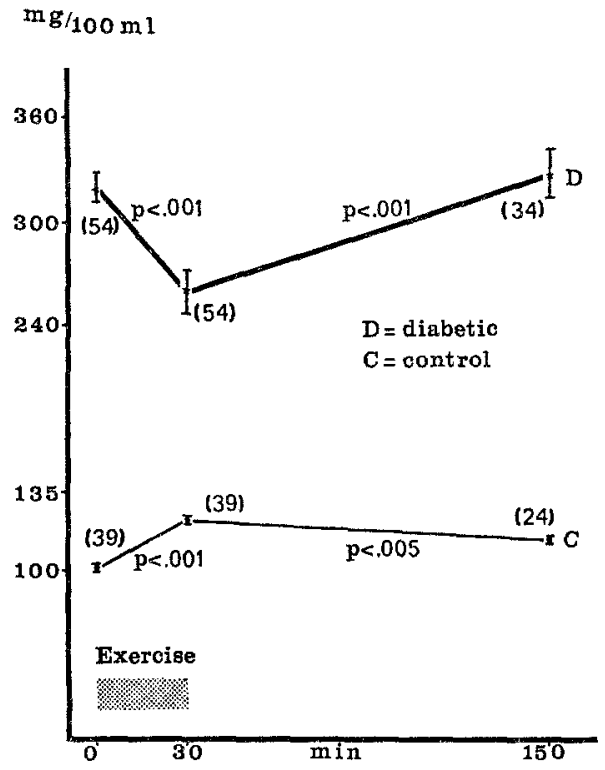

Fig. 1. Blood glucose (mg/100 ml, mean \pm SEM) before and after exercise in streptozotocin $(65 \mathrm{mg} / \mathrm{kg})$ - diabetic and control rats. The number of animals is given in brackets. The p-values refer to differences within the group

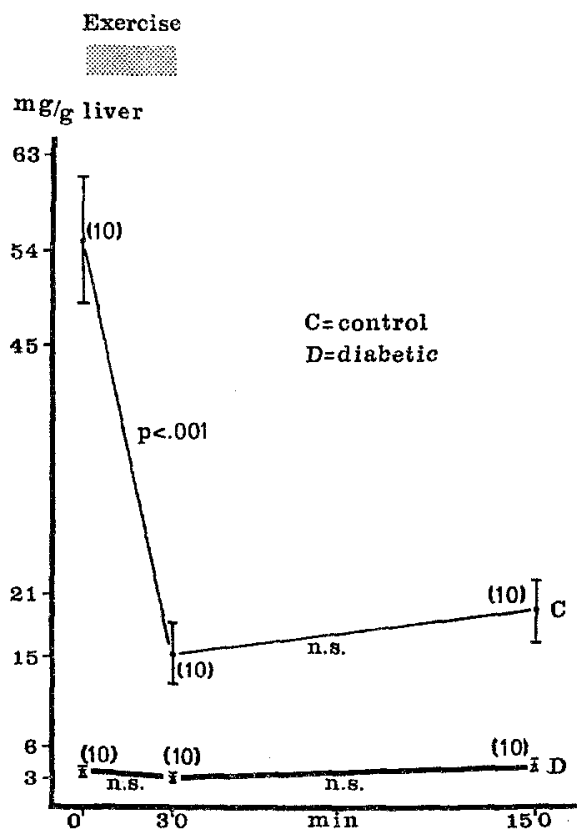

Fig. 2. Liver glycogen (mg/g liver, mean \pm SEM) before and after exercise in control and streptozotocin $(65 \mathrm{mg} / \mathrm{kg})$ - diabetic rats. The number of animals is given in brackets

\section{Pancreatic IRI}

Pancreatic content of IRI (Table 5) before exercise in diabetic rats was about $1 \%$ of that in the controls, and remained low and unchanged during and after

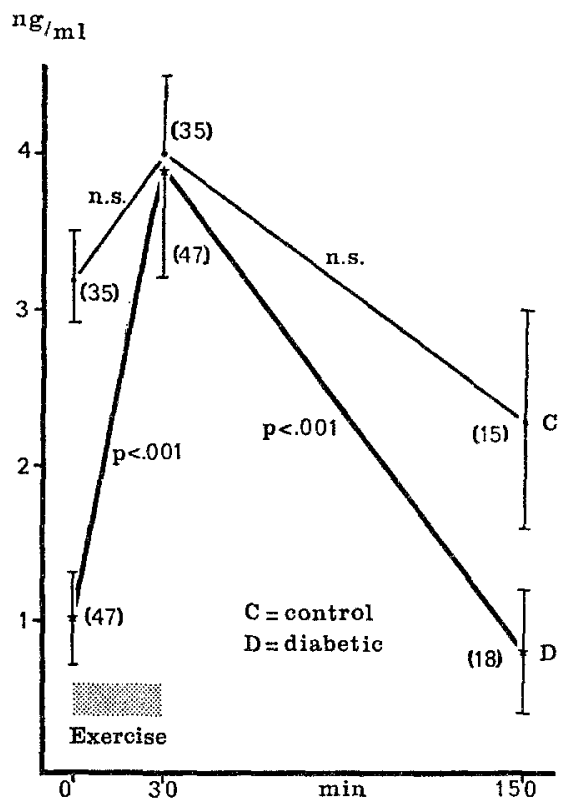

Fig. 3. Plasma IRI (ng/ml, mean $\perp$ SEM) before and after exercise in streptozotocin $(65 \mathrm{mg} / \mathrm{kg})$ - diabetic and control rats. The number of animals is given in brackets. The $p$-values refer to differences within the group

exercise. In control animals an increase of pancreatic IRI was found after exercise.

\section{Plasma Glycerol and FFA}

A marked lipid mobilizing effect of exercise, measured as an increase in plasma glycerol, is shown in Fig. 4 . The rise of plasma glycerol in the diabetic rats correlated with the enhancement of blood lactate, $\mathrm{r}=$ $0.42, p<0.01$. Simultaneously, circulating FFA diminished significantly (Fig. 5). The decrease of FFA correlated with the rise in blood glucose $(\mathrm{r}=0.66, p<$ 0.025 ), and at the end of exercise the level of circulating FFA correlated inversely with the level of lactate $(\mathrm{r}=-0.53, p<0.05)$ in those animals in which blood glucose tended to rise during exercise (group 2, Table 4). The mean values of plasma glycerol and FFA were not different in the two subgroups before or after exercise. In non-diabetic rats a typical post-exercise increase of circulating FFA was registered.

\section{Blood Acetone Bodies}

Blood total acetone bodies tended to decrease during exercise in hyperketonemic rats. The level was $5.9 \pm 0.5$ before and $4.8 \pm 0.5 \mathrm{mmol} / 1$ (mean $\pm \mathrm{SEM}$, $\mathrm{n}=41$ ) immediately after exercise. The change was insignificant during exercise, but during the recovery 
period a rise to $6.8 \pm 0.8 \mathrm{mmol} / 1$ was found $(p<0.001$ vs. immediate postmexercise value). In fractional determination a significant drop during exercise was registered in acetoacetate + acetone from $1.8 \pm 0.2$ to

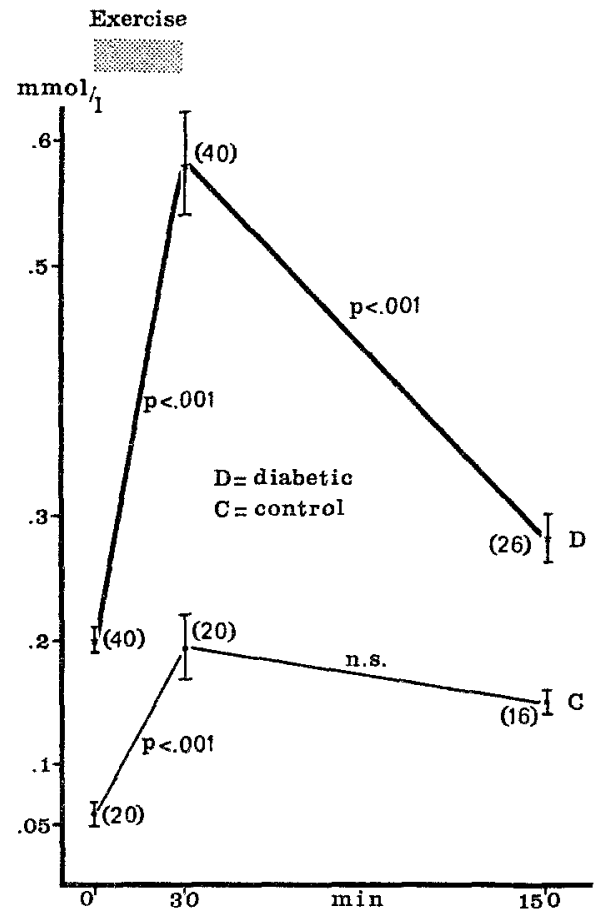

Fig. 4. Plasma glycerol ( $\mathrm{mmol} / 1$, mean \pm SEM) before and after exercise in streptozotocin $(65 \mathrm{mg} / \mathrm{kg})$ - diabetic and control rats. The number of animals is given in brackets. The p-values refer to differences within the group
$46.7 \pm 2.4 \mu \mathrm{g} / 100 \mathrm{ml}$ respectively; two hours later the level had decreased to $21.2 \pm 1.7$ in controls and $34.8 \pm 3.3 \mu \mathrm{g} / 100 \mathrm{ml}$ in diabetic rats. The diabetic subgroups (Table 4) did not differ from each other with

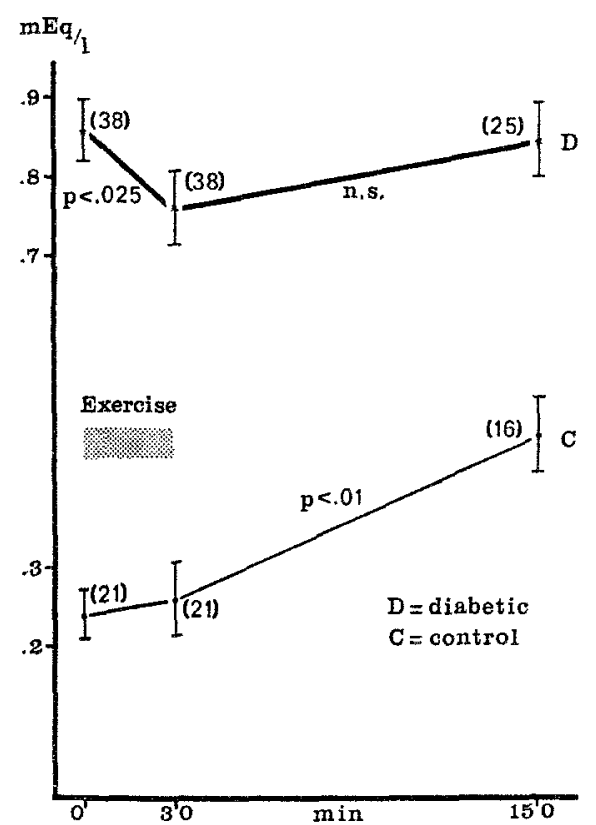

Fig. 5. Plasma FFA (mEq/l, mean \pm SEM) before and after exercise in streptozotocin $(65 \mathrm{mg} / \mathrm{kg})$ - diabetic and control rats. The number of animals is given in brackets. The p-values refer to differences within the group

Table 5. Pancreatic content of IRI ( $\mathrm{g} / \mathrm{mg}$ pancreas, mean $\pm S E M$ ) in streptozotocin $(65 \mathrm{mg} / \mathrm{kg})$-diabetic and control rats before and after $30 \mathrm{~min}$ exercise

\begin{tabular}{llll}
\hline & $\begin{array}{l}\text { Before } \\
\text { exercise }\end{array}$ & $\begin{array}{l}\text { Immdiately } \\
\text { after exercise }\end{array}$ & $\begin{array}{l}120 \text { min } \\
\text { after exercise }\end{array}$ \\
\hline Diabetic & $0.001 \pm 0.001$ & $0.004 \pm 0.001$ & $0.005 \pm 0.004$ \\
$\mathrm{n}$ & 8 & 8 & 8 \\
Control & $0.093 \pm 0.010^{\mathrm{a}}$ & $0.101 \pm 0.018$ & $0.144 \pm 0.17 \mathrm{a}$ \\
$\mathrm{n}$ & 8 & 8 & 8 \\
\hline
\end{tabular}

$\mathrm{a}=p<0.025$

$\mathrm{n}=$ the number of animals

$1.2 \pm 0.1 \mathrm{mmol} / \mathrm{l}$. The rats in which blood glucose decreased during exercise had, before and after exercise, markedly lower blood acetone bodies than the "nonresponders", but the changes showed the same direction in both subgroups. In control rats blood total acetone bodies rose during exercise from $0.27 \div 0.02$ to $0.59 \pm 0.04 \mathrm{mmol} / \mathrm{l}(\mathrm{mean} \pm \mathrm{SEM}, \mathrm{n}=12, p<0.001$ ) and remained unchanged during the recovery period.

\section{Plasma Corticosterone}

Plasma corticosterone before exercise was $11.9 \pm$ $1.5 \mu \mathrm{g} / 100 \mathrm{ml}$ (mean $\pm \mathrm{SEM}, \mathrm{n}=11$ ) in controls and $27.5 \pm 2.3 \mu \mathrm{g} / 100 \mathrm{ml}(\mathrm{n}=23)$ in diabetic rats. Immediately after exercise the values were $44.2 \pm 1.7$ and respect to plasma corticosterone level before or after exercise.

\section{Discussion}

\section{Our Experimental Model of Diabetes}

The experimental model used in this study corresponds with severe diabetes in many respects. The I.V. injection of streptozotocin at $65 \mathrm{mg} / \mathrm{kg}$ of body weight induces frank necrosis of B-cells in $7 \mathrm{~h} \mathrm{[24]} \mathrm{and}$ leads to a marked diabetes, as judged from high blood glucose, low value of pancreatic IRI $[25,26]$, loss of weight, accelerated mobilization of stored fat and 
hyperketonemia and ketonuria in Sprague-Dawley rats $[27,28]$. Our findings are in agreement with those previously reported.

\section{Metabolic and Hormonal Changes during Exercise}

The changes in blood glucose during exercise were much like those previously reported in pancreatectomized dogs by Moxness et al. [11], i.e. a considerable decrease in many of the animals but not in all of them. In our study the decrease of blood glucose in diabetic rats correlated both with the intensity of work and with the rise in plasma IRI. So, the increase of plasma IRI in most intensively working animals helps to explain the decrease in blood glucose.

Hepatic glycogen seems to play no rôle in glucose production during exercise in severely diabetic animals, although in control rats hepatic glycogen, and in healthy man glucose production by the liver [29], is a source of energy during muscular work.

The changes in circulating IRI in diabetic animals did not correspond to any variations in pancreatic IRI, at least when measuring the latter after acidethanol extraction. The binding of insulin to peripheral tissues has been shown in vitro [30] and in vivo [31]. In healthy man a release of "bound" IRI during muscular work has been previously reported from the heart [32] and the forearm [33, 34]. In dogs the release of IRI from the head and the hind limb has been achieved by rapid I.V. injection of insulin or glucose [35], and from the hind leg by acute muscular exercise [36]. - It is possible that in the diabetic rat the enhancement of plasma IRI during exercise is extrapancreatic. On the other hand, the secretion of IRI is inhibited by catecholamines [37], the secretion of which is in turn increased during exercise [38]. The rise of pancreatic IRI after exercise in non-diabetic animals (Table 5) and the decreasing tendency in plasma IRI at the same time (Fig. 3) could be explained by the inhibitory effect of catecholamines on the secretion of IRI.

The lipid mobilization, which correlated with the intensity of muscular work, was not prevented by the increase of plasma IRI from hypo- to normoinsulinemic levels. The insulin response of diabetic adipose tissue in our experimental model in vitro was not decreased during exercise [39], but lipid mobilization may be due to other hormonal effects during exercise, e.g. the enhanced secretion of catecholamines [38] and glucocorticoids [40]. We determined plasma corticosterone, which was greatly elevated in the diabetic rats before exercise and increased significantly during the experiment. Contrary to its likely effect on lipid mobilization, plasma corticosterone did not seem to affect the levels of blood glucose in relation to exercise in diabetic rats, as judged from the similar plasma corticosterone values in the "responders" and "nonresponders".

Circulating FFA diminished during exercise in spite of a simultaneous increase of lipolysis [41]. The fall in plasma FFA has been demonstrated to be related to an improved flow of FFA from plasma [42], and in pancreatectomized dogs FFA have been shown to be the major energy source during muscular work [8]. The correlation between the fall in circulating FFA and the rise in blood glucose in group 2 of diabetic rats suggests that in insulin deficiency FFA have, as an energy source, a glucose "sparing" effect during exercise.

The acidosis of markedly ketoacidotic animals worsened during muscular work because of the rise in blood lactate, whereas circulating acetone bodies tended to decrease. The diminution in blood acetone bodies may be due to a better utilization of acetone bodies during exercise [11].

Acknowledgements. This study was supported by the Yrjö Jahnsson Foundation, the Finnish Culture Fund and the Foundation for Paediatric Research in Finland. We thank professor Esko A. Nikkilä, and Drs. Sidney S. Chernick and Robert 0 . Scow for helpful advice and criticism. The skilful technical assistance of Mrs. Arja Johansson is acknowledged.

\section{References}

1. v. Noorden, C.: Die Zuckerkrankheit und ihre Behandlung, p. 497. 7. Aufl., Berlin: Hirschwald 1917

2. Carlström, S.: Studies on fatty acid metabolism in diabetics during exercise. Acta med. Scand. 186, $429-432(1969)$

3. Nordlander, S., Östman, J., Cerasi, E., Luft, R., Ekelund, L.: Occurrence of diabetic type of plasma FFA and glycerol responses to physical exercise in prediabetic subjects. Acta med. Scand. 193, 9-21 (1973)

4. Issekutz, B.Jr., Miller, H.I., Rodahl, K.: Effect of exercise on FFA metabolism of pancreatectomized dogs. Amer. J. Physiol. 205 (4), 645-650 (1963)

5. Kovacev, V., Scow, R.O.: Effect of hormones on fatty acid release by rat adipose tissue in vivo. Amer. J. Physiol. 210, 1199-1208 (1966)

6. Beatty, C.H., Marco, A., Peterson, R.D., Bocek, R.M., West, E.S.: Acetoacetic acid metabolism by skeletal muscle fibers from control and diabetic rats. J. biol. Chem. 235, 2774-2777 (1960)

7. Scow, R.O., Chernick, S.S.: Hormonal control of protein and fat metabolism in pancreatectomized rat. Recent Progr. Hormone Res. 16, 497-545 (1960)

8. Issekutz, B.Jr., Paul, P., Miller, H.I.: Metabolism in normal and pancreatectomized dogs during steady. state exercise. Amer. J. Physiol. 213 (4), 857-862 (1967)

9. Goldstein, M.S.: Humoral nature of hypoglycemia in muscular exercise. Amer. J. Physiol. 200, 67-70 (1961)

10. Dulin, W.E., Clark, J.J.: Studies concerning the possible humoral factor produced by working muscles. Its influence on glucose utilization. Diabetes 10, $289-297(1961)$

11. Moxness, K.E., Molnar, G.D., MeGuckin, W.F.: Exercise and blood glucose concentration in intact and pancreatectomized dogs. Diabetes 13, 37-43 (1964)

12. Huggett, A.St.G., Nixon, D.A. : Enzymic determination of blood glucose. Biochem. J. 66, 12 (1957)

13. Hohorst, H.J.: I-(+)-Lactat Bestimmung mit Lactat-Dehydrogenase und DPN. In: H.U. Bergmeyer (Ed.): Methoden der enzymatischen Analyse, pp. 266-270. Weinheim: Verlag Chemie 1962 
14. Andersen, S.O., Eng'el, K., Jörgensen, K., Astrup, P. A micromethod for determination of $\mathrm{pH}$, carbon dioxide tension, base excess and standard bicarbonate in capillary blood. Scand. J. clin. Lab. Invest. 12, $172-176(1960)$

15. Laurell, S., Tibbling, G.: An enzymatic fluorometric micromethod for the determination of glycerol. Clin. chim. Acta 13, 317-322 (1966)

16. Novak, M.: Colorimetric ultramicro method for the determination of free fatty acids. J. Lipid. Res. 6, $431-433(1965)$

17. Ahola, T., Somersalo, O.: Microdetermination of acetone bodies in blood and urine. Ann. Med. exp. Fenn. 41, 237-246 (1963)

18. Herbert, V., Lau, K.-S., Gottlieb, C.W., Bleicher, S.J.: Coated charcoal immunoassay of insulin. $J$. clin. Endocr. 25, 1375-1384 (1965)

19. Spencer-Peet, J., Daly, J.R., Smith, V.: A simple method for improving the specifity of fluorometric determination of adrenal corticosteroids in human plasma. J. Endocr. 31, 235-244 (1965)

20. Chernick, S.S., Chaikoff, I.L., Masoro, E.J., Isaeff, F.: Lipogenesis and glucose oxidation in the liver of alloxan-diabetic rat. J. biol. Chem. 186, 527-542 (1950)

21. Grodsky, G., Tarver, H.: Paper chromatcirraphy of insulin. Nature (London) 177, 223-225 (1956)

22. Taylor, K.W., Parry, D. G., Smith, G.H. : Biosynthetic labelling of mammalian insulins in vitro. Nature (London) 203, 1144-1145 (1964)

23. Koivisto, V.A., Kiviluoto, M.K., Åkerblom, H.K., Oksanen, A.: The role of hepatic glycogen as a fuel for exercise in diabetic and non-diabetic rats. Acta Endocr. (Kbh.) 75, Suppl. 181, 22-23 (1974)

24. Junod, A., Lambert, A.E., Orci, L., Pictet, R., Gonet, A.E., Renold, A.: Studies of the diabetogenic action of streptozotocin. Proc. Soc. exp. Biol. Med. 126, 201-205 (1967)

25. Junod, A., Lambert, A.E., Stauffacher, W., Renold, A.E.: Diabetogenic action of streptozotocin: relationship of dose to metabolic response. J. clin. Invest. 48, 2129-2139 (1969)

26. Rerup, C.C.: Drugs producing diabetes through damage of the insulin secreting cells. Pharmacol. Rev. 22, 485-517 (1970)

27. Förster, O., Rudas, B.: Ketosis in rats with streptozotocin induced diabetes. Lancet 1969 I, 1321-1322

28. Rudas, B.: Streptozotocin. Arzneimittel-Forsch. 22, $830-861$ (1972)

29. Hultman, E.: Studies on muscle metabolism of glycogen and active phosphate in man with special reference to exercise and diet. Scand. J. clin. Lab. Invest. 19, (Suppl. 94) (1967)
30. Krahl, M.E.: The action of insulin on cells, p. 169. New York: Academic Press 1961

31. Rafaelsen, O.J., Lauris, V., Renold, A.E.: Localized intraperitoneal action of insulin on rat diaphragm and epididymal adipose tissue in vivo. Diabetes 14, $19-26(1965)$

32. Wahlqvist, M.L., Kaijser, L., Lassers, B. W., Löw, H., Carlson, L.A.: Release of immunoreactive insulin from the human heart. Europ. J. clin. Invest. 2, $407-411(1972)$

33. Dieterle, P., Gmeiner, K.-H., Henner, J., Dieterle, C., Schwarz, K.: Evidence for peripheral release of insulin during muscular work in man. Horm. Metab. Res. 4, 54 (1972)

34. Dieterle, P., Birkner, B., Gmeiner, K.-H., Wagner, P. Erhardt, F., Henner, J., Dieterle, C.: Release of peripherally stored insulin during acute muscular work in man. Horm. Metab. Res. 5, 316-322 (1973)

35. Rasio, E.A.: The displacement of insulin from blood capillaries. Diabetologia 5, 416-419 (1969)

36. Metzger, P., Rogister, C., Tinant, A., Conrad, V.: Influence of muscular exercise on glucose utilization. Diabetologia 8, 58 (1972)

37. Porte, D.J., Williams, R.H.: Inhibition of insulin release by norepinephrine in man. Science $\mathbf{1 5 2}$, $1248-1250$ (1966)

38. Kärki, N.: The urinary excretion of noradrenaline and adrenaline in different age groups, its diurnal variation and the effect of muscular work on it. Acta physiol. scand. 39, (Suppl. 132) (1957)

39. Koivisto, V.A., Åkerblom, H.K., Kiviluoto, M.K.: The in vitro response of adipose tissue to exercise in diabetic rats. Excerpta med. (Amst.) 280, 216 (1973)

40. Venning, E.H., Kazmin, V.: Excretion of urinary corticoids and 17-ketosteroids in the normal individual. Endocrinology 39, 131 - 139 (1946)

41. Carlson, L.A., Elkelund, L.G., Orö, L.: Studies on blood lipids during exercise. IV. Arterial concentration of plasma free fatty acids and glycerol during and after prolonged exercise in normal men. J. Lab. clin. Med. 61, 724-729 (1963)

42. Friedberg, S.J., Harlan, W.R. Jr., Trout, D.L., Estes, E.H. Jr.: The effect of exercise on the concentration and turnover of plasma nonesterified fatty acids. J. clin. Invest. 39, 215-220 (1960)

V.A. Koivisto, M.D.

The Children's Hospital

University of Helsinki

11 Stenbäck Street

SF-00290 Helsinki 29

Finland 